\title{
Issues and Trends of Depression among Students in Malaysia
}

\author{
Nor Asikhin Ishak ${ }^{1, *}$, Nor Shafrin Ahmad ${ }^{1}$, Mohd Norakmar Omar ${ }^{2}$ \\ ${ }^{1}$ School of Education Studies, Universiti Sains Malaysia, Georgetown, 11800 Pulau Pinang, Malaysia \\ ${ }^{2}$ School of Education and Modern Languages, Universiti Utara Malaysia, Sintok, 06010 Kedah, Malaysia
}

Received August 18, 2020; Revised September 28, 2020; Accepted October 19, 2020

\begin{abstract}
Cite This Paper in the following Citation Styles
(a): [1] Nor Asikhin Ishak, Nor Shafrin Ahmad, Mohd Norakmar Omar, "Issues and Trends of Depression among Students in Malaysia," Universal Journal of Educational Research, Vol. 8, No. 11B, pp. 5951 - 5957, 2020. DOI: 10.13189/ujer.2020.082230.
\end{abstract}

(b): Nor Asikhin Ishak, Nor Shafrin Ahmad, Mohd Norakmar Omar (2020). Issues and Trends of Depression among Students in Malaysia. Universal Journal of Educational Research, 8(11B), 5951-5957. DOI: 10.13189/ujer.2020.082230.

Copyright $\bigcirc 2020$ by authors, all rights reserved. Authors agree that this article remains permanently open access under the terms of the Creative Commons Attribution License 4.0 International License

\begin{abstract}
Depression is an emotional disease that is increasingly serious among teenagers today, mostly involving school students. This situation is very worrying when student depression can lead to worse incidents such as criminal behaviors, social problems, and suicide. Therefore, this study aims to identify the depression levels of secondary school students in North Penang, Malaysia. A total of 3932 form four students were involved as a study sample using the Depression Anxiety Stress Inventory 21 (DASS21) instrument adapted from the Ministry of Health, Malaysia (MOH). The study conducted concerning research ethics, such as obtaining permission from the Penang State Education Department, the school, and students' heirs. The result found that $72.6 \%$ of students had normal depression, and $12.5 \%$ of students found to have lite depression only. Overall, it can be concluded that most students experience depression even at the lowest level. Students need to be given due attention, including emphasizing the aspects of guidance and counseling to lead a better life in the future. Thus, preventive measures should be planned systematically. A study of the need for counseling intervention modules should be implemented to help reduce school student depression.
\end{abstract}

Keywords Mental Health, Depression, Adolescent Issues, School Students, Malaysia

\section{Introduction}

The social problem is an issue that often gets attention and interest among people around the world. It can say that any issue of social problems will be a heated conversation and discussion, especially involving teenagers, especially school students. The evolutionary change of world civilization from antiquity to the digital age has seen students today increasingly squeezed by various social problems [1]. This technological world's rapid pace is opening wide to students to explore and try something new without realizing that such behavior can pose a considerable risk [2].

Apart from fighting against the words of teachers and school rules, students nowadays are increasingly daring to stand out with various large-scale social problems. These people not only dare to smoke and bully, but some are willing to carry out criminal activities such as stealing and robbery [3]. The most worrying thing is that they can do things beyond rational thinking limits such as prostitution, abortion, and committing brutal murder [4].

Social problems among these students have become a national issue around the world. This situation becomes a concern to all parties, including parents, teachers, the community, and even the government. Several factors have been identified among the causes of such behavior's rapid onset by students, such as psychological and socio-emotional [1],[5]. In other words, a high level of depression will result in students having the intention to perform harmful activities [6].

Students are an asset to the nation's top leadership development and pioneer in times of hope. Students become the lifeblood and need a country to provide a 
group of human resources who can diversify their sources of expertise such as thinking, spirituality, and technology [7]. However, the students' reluctance to act in vain will invite a dark future to the country [8]. As a result of this problem, the issue of depression becomes an issue debated by scholars because it is a basis for the formation of a teenager who will do immoral activities [9],[10].

Decades ago, scholars disagreed that depression could exist among children and adolescents, especially school students [11]. However, the changes of the times have proven that there are already signs of depression among students. As a result, students experience severe and unpredictable depression [12],[13]. Studies from [14] also emphasize that students can get depressed due to parents who often make strict antisocial controls. As a result, they will rebel and try to implement behavior outside the influence of everyday thinking.

Therefore, students should give the best attention and education so that their depression level does not worsen. According to [15], the best approach and intervention needs to implement immediately as students today exposed to various social problems due to the rapid development of the times. Among the approaches used are counseling interventions and specialized modules of depression capable of generating a sense of peace, happiness, love, self-satisfaction, and well-being [16],[17]. Thus, this study will touch in more detail related to the level and trend of depression involving secondary school students in Malaysia's educational development environment.

\section{Literature Review}

\subsection{Definition of Depression}

Depression can be a symptom such as sadness, guilt, lack of self-esteem, not feeling happy and unhappy with what is happening around them [13]. Besides, depression can also make individual problems such as trouble in sleeping, loss of appetite, lack of energy, easy to despair so that he can think of suicide [17]. Those who suffer from depression cannot reason and try to act according to abnormal thinking when challenging to control.

According to the [18], the signs of a person getting depressed are at least five depression symptoms present to them for two consecutive weeks. Based on the organization's study, depression will be the second-highest cause on the list of human emotional health problems by 2020. This case further strengthened when the [19] stated that at least 350 million people worldwide are actively undergoing deprivation nowadays.

Depression can also be term as a feeling of sadness that strikes an individual [20]. However, the word may be a bit rough to adopt, which leads to a meaning that can adapt to various situations and the situation of an event [21]. In medicine, depression is also considered a clinical disease and should be treated accordingly [12].

Usually, every individual will experience feelings of sadness or gloom even once in a certain period of his life [22]. For some individuals, these emotional disorders or depression occur only for a short period. However, feelings of depression can persist for an extended period if there are severe cases. Prolonged depression is an indicator of negative behaviors such as suicide and a severe mental illness [23]. There is no denying that depression is risky in affecting an individual's cognitive, emotional, social, and physical life.

\subsection{Issues and Trends of Depression among Students}

Based on previous studies, there is clear evidence that depression is a common problem often faced by adolescents, especially school students [4],[24],[25]. According to a study from [26], student depression can reach 33\% level based on the definition, assessment, and seriousness of the level of depression they face. Meanwhile, [27] found that one in five students will experience depression in their lives. There are $20 \%$ of students who will experience depression if no extreme action is taking against them.

Student depression is an important aspect to be studied in depth because past studies show that about $20 \%$ of students experience severe depression [28]. Besides, [29] found that female students had twice the rate of depression than male students as young as 15 years old. This situation exists because female students tend to harbor feelings, have negative image feelings, discriminate, and mature faster than male students. Therefore, the average female student has started to show a sudden change in attitude when she is in high school again.

Meanwhile, family issues can also pose a risk of depression in students. Family problems such as parental disputes, declining parental emotional levels, parents experiencing stress and financial problems are among the causes of students also feeling depressed leading to depression [2],[28]. In reality, students find it difficult to control feelings of depression when they are in an unhealthy environment while at home as well as experiencing emotional disorders caused by other factors such as learning problems [22].

There is also the existence of depression among students due to poor relationships with peers at school. Situations such as not having a right partner, lack of attention, and rejection from peers can invite a more severe tendency to depression [30]. However, the depression rate of female and male students is still at a low level, depending on the type of friendship and conflict that occurs between them [31].

In Malaysia, depression is the fourth most dangerous disease in society [32]. From the study, adolescents are 
the most at-risk individuals to have high rates of depression. It also reported that $2.4 \%$ of adolescents aged between 16 until 24 years are at risk of experiencing negative behaviors such as suicide due to depression [33]. This matter is very worrying because among these groups are students who are still studying in school and not mature enough in making decisions in life.

\section{Methodology}

This study conducted quantitatively using cross-sectional research methods. Given the study's location and many respondents, quantitative research is an appropriate option to collect research data more efficiently, quickly, and easily analyzed [34]. Roughly speaking, the study will focus on the level of student depression detected among secondary school students around Penang. The trend of depression will analyze in more depth.

\subsection{Population and Sampling}

This study is conducting in 24 secondary schools around the North of Penang, Malaysia. These schools were selected based on the school placement location, which is the scope of the study location. Of the 24 schools, a total of 3932 students selected as participants. These students comprise four students in all schools, and students selected based on simple random sampling.

After that, a list of student names obtained in advance from each school involved. Then, the researcher submits the questionnaire to the selected respondents. The school cooperates well when they provide a special session to provide information on the implementation of the study. This method is more efficient than other methods because the data can be collected faster, and the rate of return is higher [35].

\subsection{Instrumentation}

This study conducted using the Depression Anxiety Stress Inventory 21 (DASS21) measuring instrument adapted from the Ministry of Health Malaysia [36]. Five items describe depression in DASS21. These depression items use in various studies of students' depression in Malaysia, as in the study of [17] and [37]. Based on their study, the DASS instrument's Cronbach alpha reliability value is high at around $0.75-0.95$.

A pilot study is conducting to ensure the reliability value of the depression items in DASS21. The test results found that the Cronbach's alpha value for the depression items was 0.80 . This situation has convinced the researcher that depression items can measure the level of student depression in this study. This situation is agreed by [35], who stated that the reliability value of study items should exceed 0.70 to prove that these items can measure the study's objectives more perfectly.

The Ministry of Health Malaysia (MOH) has stated that the items used to measure the level of depression result from careful research based on the experiences of depressed patients before. Thus, MOH found that depression items are inseparable of some aspects such as negative feelings, inability to start a new life, hopelessness, feelings of sadness, and lack of enthusiasm in life [17], [36]. Therefore, the following items listed as items that can measure depression listed in Table 1 below.

Table 1. Items for depression

\begin{tabular}{|c|c|}
\hline Code & Items \\
\hline D1 & I cannot feel positive. \\
D2 & I am not eager to start a situation \\
D3 & I guess nothing I expected. \\
D4 & I feel gloomy and sad. \\
D5 & I am not directly interested in life. \\
\hline
\end{tabular}

\subsection{Data Analysis}

Study data were collected and analyzed using Statistical Package for the Social Sciences (SPSS) version 24.0 software. The analysis involved is like a descriptive analysis to determine the levels of participant depression. The level of depression determined by the accumulated score obtained by a respondent-based on each item they answered starting from 0 (never), 1 (rare), 2 (frequent) and 3 (very frequent). Students need to answer the five questions posed by marking a score between one until four on each question.

There are five levels of depression divided in this study proposed by [36]. These levels are a standard used during test times to categorize the levels of depression experienced by an individual. According to [17], each question has a score starting from the value of 0 to 4 . Maximum, a student can achieve a very severe level of depression when they answer all of five questions with a score of 4 . This situation means he recorded a score of 20 marks as a whole.

However, a student can show a standard sign of depression when he answers at least with a value of 0 for all five questions posed. In other words, the student cumulatively does not have depression because he recorded a score of 0 . In conclusion, the calculation of the level of depression is as follows:

$$
\text { Total Scores }=(\mathrm{Q} 1+\mathrm{Q} 2+\mathrm{Q} 3+\mathrm{Q} 4+\mathrm{Q} 5) \text { scores. }
$$

When all the five questions' score values are a mix, then the level of student depression can be obtained. The measurement of student depression levels based on the following Table 2. This table shows that students who get five marks and below are categorized as average levels of depression, while students who achieve 14 marks and above experience severe depression. 
Table 2. Levels of student depression

\begin{tabular}{|c|c|c|}
\hline Level & Description of Depression & Total Score \\
\hline 0 & Normal & $0-5$ scores \\
1 & Lite depression & $6-7$ scores \\
2 & Moderate depression & $8-10$ scores \\
3 & Severe depression & $11-14$ scores \\
4 & Very severe depression & $14-20$ scores \\
\hline
\end{tabular}

\subsection{Research Ethics}

The DASS21 instrument is an instrument proposed by [36] and used in every school every year. Therefore, the school, assisted by the counselor, is responsible for conducting the test to all students in their school. In other words, students and heirs have agreed to take the DASS2 1 test as it is a mandatory test to be implemented every year.

Even so, researchers also took the approach of using the right channels to obtain research data. Before the study, the researcher obtained permission from the Educational Planning and Policy Research Division (EPRD) and the Penang State Education Department (JPNPP). Later, the researcher made an initial notification to the school to inform the students that a study will conduct related to student depression.

Although DASS21 data can obtained through school counselors, the researchers themselves come to the school to perform the test. The presence of researchers gives the impression that the test sessions conducted are crucial, and the data collected is born from the students' sincerity. Researchers also explained that the data of this study is confidential and used for research purposes only.

\section{Findings}

\subsection{Levels of Student Depression}

Table 4 shows the number of students involved in this study categorized based on their level of depression. The analysis shows that very severe depression is present from nine students $(5.8 \%)$ from school I, while six students (5.2\%) from school B. Meanwhile, as many as 18 schools in North Penang do not have students categorized as depression is very severe. It is a good sign for the school, especially in creating the concept of goodwill learning.

Besides, Table 4 also shows the findings for normal levels of student depression. The result that students in school Q had the highest percentage of normal levels of depression at 463 students (98.5\%) followed by school V with 148 students (91.9\%) and school N with 84 students (90.4\%). These findings illustrate that school students are less depressed and can continue living as perfectly as other standard students.
Table 4. Number of students based on level of depression

\begin{tabular}{|c|c|c|c|c|c|c|}
\hline \multirow{2}{*}{ School } & \multicolumn{5}{|c|}{ Level of Depression } & \multirow{2}{*}{ Tota } \\
\hline & $\mathbf{0}$ & 1 & 2 & 3 & 4 & \\
\hline A & 45 & 30 & 46 & 0 & 0 & 121 \\
\hline B & 58 & 21 & 23 & 6 & 6 & 114 \\
\hline $\mathrm{C}$ & 103 & 28 & 22 & 1 & 1 & 155 \\
\hline D & 149 & 5 & 6 & 0 & 0 & 160 \\
\hline $\mathrm{E}$ & 127 & 36 & 24 & 13 & 4 & 204 \\
\hline $\mathrm{F}$ & 63 & 66 & 25 & 9 & 0 & 163 \\
\hline $\mathrm{G}$ & 112 & 60 & 40 & 6 & 5 & 223 \\
\hline $\mathrm{H}$ & 64 & 16 & 23 & 7 & 1 & 111 \\
\hline I & 63 & 31 & 30 & 22 & 9 & 155 \\
\hline $\mathrm{J}$ & 87 & 16 & 21 & 3 & 0 & 129 \\
\hline $\mathrm{K}$ & 280 & 55 & 34 & 20 & 4 & 393 \\
\hline $\mathrm{L}$ & 141 & 0 & 7 & 0 & 0 & 148 \\
\hline M & 93 & 10 & 17 & 0 & 0 & 120 \\
\hline $\mathrm{N}$ & 84 & 5 & 5 & 0 & 0 & 94 \\
\hline $\mathrm{O}$ & 20 & 4 & 11 & 0 & 0 & 35 \\
\hline $\mathrm{P}$ & 63 & 5 & 6 & 0 & 0 & 74 \\
\hline Q & 463 & 1 & 0 & 6 & 0 & 470 \\
\hline $\mathrm{R}$ & 82 & 16 & 24 & 0 & 0 & 122 \\
\hline $\mathrm{S}$ & 87 & 6 & 10 & 0 & 0 & 103 \\
\hline $\mathrm{T}$ & 130 & 36 & 41 & 0 & 0 & 207 \\
\hline $\mathrm{U}$ & 184 & 13 & 23 & 3 & 3 & 226 \\
\hline V & 148 & 0 & 13 & 0 & 0 & 161 \\
\hline W & 64 & 13 & 14 & 0 & 0 & 91 \\
\hline$X$ & 144 & 17 & 0 & 0 & 0 & 153 \\
\hline Overall & 2854 & 490 & 465 & 96 & 33 & 3932 \\
\hline
\end{tabular}

\subsection{Overall Student Depression Trends}

Table 5 shows the overall student depression level for students in secondary schools in North Penang, Malaysia. The analysis found that a total of 2854 students $(72.6 \%)$ of secondary schools in North Penang classified as depression at a healthy level. This number decreased when only 490 students (12.5\%) found to have lite levels of depression. In comparison, another 465 students (11.8\%) experienced moderate levels of depression. Besides, data analysis also showed that 96 students (2.4\%) have severe levels of depression. Besides, the remaining 33 students $(0.8 \%)$ have very severe levels of depression.

Table 5. Student depression trends by category

\begin{tabular}{|c|c|c|c|}
\hline Level of Depression & Total Score & $\mathbf{N}$ & $\mathbf{\%}$ \\
\hline Normal & $0-5$ scores & 2854 & 72.6 \\
Lite depression & $6-7$ scores & 490 & 12.5 \\
Moderate depression & $8-10$ scores & 465 & 11.8 \\
Severe depression & $11-14$ scores & 96 & 2.4 \\
Very severe depression & $14-16$ scores & 33 & 0.8 \\
\hline
\end{tabular}

From Table 5, it found that the trend of student depression in this study decreased from normal to very severe depression. The difference is significant, involving a vast number of 2821 students or $71.8 \%$. This trend is excellent if observed as a whole. However, the total number of 33 students at a very severe depression level is an excellent guide and needs further attention. Overall, the trend of student depression in secondary schools around North Penang can illustrate in Figure 1 below. 


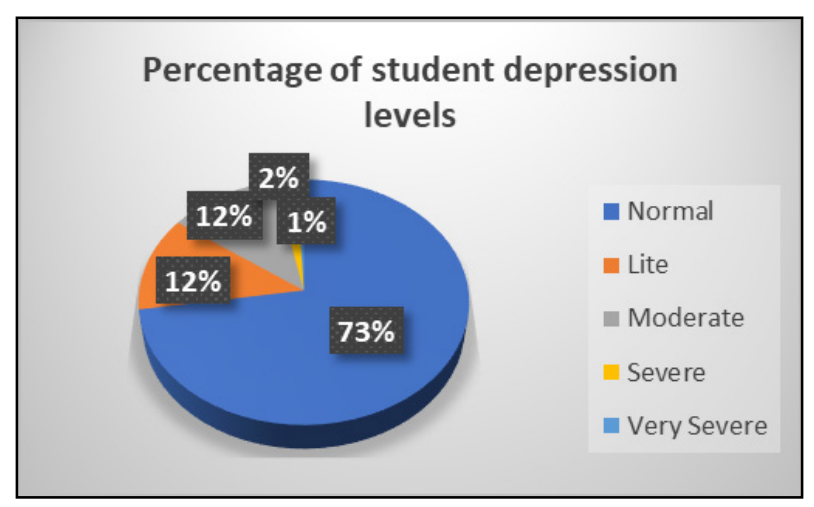

Figure 1. Percentage of student depression levels

Figure 1 found that the trend of student depression in Penang, and the majority is at an average level. The normal level is the level of depression that is highly desired by each of the school students. In simple terms, an average level of depression means that the student does not have any depression. Like other students, they can perform their daily tasks well, living each day entirely as a teenager.

Typical students will also feel positive and will always try to make changes towards goodness without hesitation. They usually have a strong determination to achieve the desired ambition as well as try to achieve it by any means. What is most important is that they do not feel sad or cheap despite facing any painful situation in life. They are also not easily discouraged and often make failure a force to improve themselves for the better.

\section{Discussions}

Nowadays, social problems are increasing among teenagers, especially school students. This increase is due to various problems, including depression that plagued school students. Previously, many factors led to depression, such as family problems, peer rejection, and having a negative image in themselves [28],[31]. Therefore, this study conducted to identify the levels of student depression so that an initial action can curb social problems resulting from prolonged depression.

This study found that $0.8 \%$ or 33 of the 3932 form four students in secondary schools around North Penang suffer from severe depression. Although the number is relatively small, this rate still raises concerns to school people, especially teachers, in educating students to be noble characters and have a strong identity and purpose in life. Painful situations may occur. The proliferation of depression rates will increase as students today are increasingly squeezed by various age changes and unhealthy cultures from abroad [3].

Earlier, a study by [39] concluded that $6 \%$ of their study sample had a clinical depression rate only. Nevertheless, [40] found that students' depression increased when $9.75 \%$ of their study sample had moderate to severe depression. Changes in time saw [41] study found that $43.41 \%$ of students experienced very high clinical depression levels.

Such studies may be conducted based on differences in measuring instruments, sampling, location, and even the study environment. However, their study results give a clear picture that the trend of depression levels is increasing day by day. It is evident in this study that students who suffer from normal depression are only $73 \%$, and the remaining $27 \%$ have various depressive symptoms. For example, $12.5 \%$ of students with lite depression, while $11.8 \%$ of students suffer from moderate depression. Suppose the rate of depression at this intermediate stage is not curbing. In that case, it may increase to severe and very severe levels [9],[24].

Increasing the rate of depression is implemented in secondary schools around North Penang, only where the study location is urban and suburban population locations. Level differences may occur when studies conducted in other locations involving students living in rural or remote areas. However, [42] found that students can access all materials online with the current state of the digital age easily, especially using mobile technology devices. This situation is a little worrying because students with signs of depression will probably use any method to rebel and lead to social problems [6]. It is also possible that these groups can use any of the latest technology media in finding ways to overcome their depression.

This study also concluded that almost students experienced moderate to high levels of depression. This condition raises a concern if not prevented from the beginning. Accordingly, integrated counselling is needed for the early prevention process to begin at a moderate level before student depression in the majority spreads to a high level. However, referrals of psychiatrists and medications should give to students with high depression [4]. In this case, as much as possible, early prevention should be implemented in a structured manner so that student depression at a moderate level can be reduced by more than $90 \%$ to a lite level.

Besides, the study also contributes to the development of theory using the DASS21 instrument approach. Previously, DASS21 has been used in every school to measure the level of student depression. Students will undergo a depression test based on the items presented in DASS21 each year [17]. It turns out that this study is in line with the view [36] where DASS21 can provide more accurate answers to identify the level of depression of school students.

\section{Conclusions}

Depression is an emotional disease that comes from unstable feelings such as sadness, low self-esteem, lack of 
fun, and self-guilt. This disorder will affect students' health and can even invite more significant social problems such as stealing, robbing, and even killing [4]. This situation worries all parties, not only the parents but the entire school community. If depression is not curbing, students will likely take unexpected actions to commit suicide [43].

Therefore, this study conducted to determine student depression levels, starting from the age of 16 years. The study's implementation coincides with the view of [27], who agreed that adolescents would begin to feel depressed when they start setting foot in high school. The study also showed a concern when $24.3 \%$ of students had begun to experience depression at lite and moderate levels. Therefore, a method needed to refine to reduce student depression not to reach severe levels.

Some schools may see that depression is less important than other serious problems such as skipping school, smoking, or gangsterism. This situation makes depression a problem that is hidden behind other problems and lacks awareness in society. Thus, this study can give a comprehensive picture that depression is not a common problem. However, each party needs to learn from the black events that have occurred over the years.

Besides, this study has enormous implications for counseling, especially involving counseling services in schools. As a teacher or school counselor, they must be aware that the standard of education in Malaysia is increasing day by day due to the changing times and education policies formulated for school people's well-being. Therefore, this study clarifies that every counselor should be aware and finds the best intervention to overcome student depression, starting from age as early as possible [44]. Prevention of this level of depression can be a reality when all parties, including parents, teachers, and the community, work together to help students address social problems before the situation worsens.

\section{Acknowledgments}

This article was conducted as part of a doctoral study by the first author at Universiti Sains Malaysia. The first author is also a student-sponsored under the Federal Training Prize Scheme (HLP) of the Ministry of Education Malaysia.

\section{REFERENCES}

[1] A. N. Pailing, and R. L. E. P. Reniers, "Depressive and socially anxious symptoms, psychosocial maturity, and risk perception: Associations with risk-taking behaviours", PLoS ONE, vol. 13(8), pp. 14-16, 2018.

[2] A. Ahmad, "Kesan intervensi psiko-pendidikan terhadap tingkah laku murid sekolah menengah oleh guru bimbingan dan kaunseling", Doctoral thesis, Universiti Kebangsaan Malaysia, 2013.

[3] H. Hussin, "Kesan intervensi terapi kelompok tingkahlaku kognitif terhadap ekstrim kendiri dan lokus kawalan dalam kalangan penagih dadah", Doctoral thesis, Universiti Sains Malaysia, 2013.

[4] V. Nejati, F. Alipour, and M. Sharifi, "Risk-taking comparison in adolescent girls with symptoms of anxiety, depression, stress and normal", Feyz, vol. 20(6), pp. 566-573, 2017.

[5] O. J. Ekundayo, J. Dodson-Stallworth, M. Roofe, I. B. Aban, M. C. Kempf, J. E. Ehiri, and P. E. Jolly, "Prevalence and correlates of depressive symptoms among high school students in Hanover, Jamaica", The Scientific World Journal, vol. 7, pp. 567-576, 2007.

[6] O. Karakus, "Depression and hopelessness levels of university students according to their opinions on finding employment or falling out of labor force in Turkey", Universal Journal of Educational Research, vol. 6(1), pp. 190-194, 2018.

[7] M. S. Mahmood, and M. K. Othman, "Learning style practices and critical thinking of students in Malaysia. Universal Journal of Educational Research, vol. 8(8), pp. 3570-3578, 2020.

[8] M. F. H. Nordin, and M. K. N. Che, "Tinjauan kepentingan pembangunan modal insan di Malaysia", Jurnal Al-Tamaddun, vol. 7(1), pp. 75-89, 2012.

[9] A. H. Ismail, "Kemurungan, sokongan sosial dan pencapaian akademik dalam kalangan pelajar sekolah menengah di luar bandar", Master dissertation, Universiti Kebangsaan Malaysia, 2011.

[10] A. A. Rahman, R. A. Rahman, S. B. Ismail, M. I. Ibrahim, S. H. Ali, H. Salleh, and W. A. M. Wan Muda, "Factors associated with attitude toward premarital sexual activities among school-going adolescents in Kelantan, Malaysia", Asia-Pacific Journal of Public Health, vol. 27(2), 15491556, 2015.

[11] M. T. Erickson, "Behavior disorders of children and adolescents: Assesement, etiology and intervention", Englewood Cliffs, NJ: Prentice-Hall Inc, 1992.

[12] U. S. Shelke, P. C. Patel, R. R. Kunkulol, V. D. Phalke, and S. P. Narwane, "Study of depression among adolescent students of rural maharashtra and its association with socio-demographic factors: a cross-sectional study", International Journal of Medical Research \& Health Sciences, vol. 4(1), pp. 41-45, 2015.

[13] J. P. De Aquino, A. Londono, and A. F. Carvalho, “An update on the epidemiology of major depressive disorder across cultures", In Kim Y. K. (eds) Understanding Depression. Springer, Singapore, 2018.

[14] Y. C. Tu, H. C. Lee, H. Y. Chen, and T. F. Kao, “A study on the relationships among psychological control, adolescent depression and antisocial behavior in Taiwan", Procedia Social and Behavioral Sciences, vol. 122, pp. 335-343, 2014.

[15] L. A. Dardas, “A nationally representative survey of 
depression symptoms among Jordanian adolescents: associations with depression stigma, depression etiological beliefs, and likelihood to seek help for depression", Doctoral dissertation, Duke University, 2017.

[16] C. D. Ryff, "Happiness is everything, or is it? explorations on the meaning of psychological well-being", Journal of Personality and Social Psychology, vol. 57(6), pp. 10691081, 1989.

[17] J. Kaur, S. M. Cheong, B. M. Naidu, G. Kaur, M. A. Manickam, M. M. Noor, ... and A. Rosman, "Prevalence and correlates of depression among adolescents in Malaysia", Asia-Pacific Journal of Public Health, vol. 26(5 Suppl), pp. 1-10, 2014.

[18] America Pscychology Association, "Diagnostic and statistical manual of mental disorders (DSM-5)", Arlington: American Psychiatric Pub, 2013.

[19] World Health Organization "Mapping actions for adolescent mental health" Retrieved February 26, 2019, from http://whqlibdoc.who.int/publications/2012.

[20] R. Wicks-Nelson, and A. C. Israel, "Behavior disorders of childhood ( $5^{\text {th }}$ edition)". Englewood Cliffs, NJ: Prentice-Hall Inc, 2003.

[21] J. J. Haugaard, "Problematic behaviors during adolescence", New York: Mcgraw-Hill Companies, Inc, 2001.

[22] D. H. Romero, S. A. Riggs, and C. Ruggero, "Coping, family social support, and psychological symptoms among student veterans", Journal of Counseling Psychology, vol. 62(2), pp. 242-252, 2015.

[23] E. T. Esperanza, and F. Bulusan, "Stressors and coping mechanisms of college scholarship grantees: A quantitative case study of an island higher education institution", Universal Journal of Educational Research, vol. 8(5), pp. 2156-2163, 2020.

[24] H. Zakaria, "Kemurungan dalam kalangan remaja di daerah Gombak, Selangor", Master dissertation, Universiti Kebangsaan Malaysia, 2011.

[25] J. W. Santock, "Life Span Development (Fourteenth)". McGraw-Hill International Edition, 2016.

[26] J. E. Costello, and A. A. A. Erkanli, "Is there an epidemic of child or adolescent depression?", Journal of Child Psychol Psychiatry, vol. 47(12), pp. 1263-1271, 2006.

[27] J. Garber, "Depression in children and adolescents: linking risk research and prevention", Am Journal Prev Med., vol. 31(6), pp. 104-25, 2006.

[28] Graber, and Sontag, "Internalizing problems during adolescence", In R. M. Lerner and L. Steinberg. In Handbook of adolescent psychology (3rd ed.). New York: Wiley, 2009.

[29] N. Hoeksema, “Abnormal psychology (5th ed.)”, New York: McGraw-Hill, 2011.

[30] J. A. Kistner, C. F. R. David-Ferdon, and T. E. Joiner, "Bias and accuracy of childrens' perceptions of peer acceptance: Prospective associations with depressive symptoms",
Journal of Abnormal Child Psychology, vol. 34, pp. 349$361,2006$.

[31] M. Brendgen, V. Lamarche, B. Wanner, and F. Vitaro, 'Links between friendship relations and early adolescents' trajectories of depressed mood", Developmental Psychology, vol. 46, pp. 491-501, 2010.

[32] S. Aishvarya, T. Maniam, H. Sidi, and T. P. S. Oei, "Suicide ideation and intent in Malaysia: A review of the literature" Comprehensive psychiatry, vol. 55, pp. 95-100, 2014.

[33] M. N. Azyyati, M. S. Fariza, and H. H. Salasiah, "Ciri-ciri remaja berisiko: kajian literatur", Islamiyyat, vol. 35(1), pp. 111-119, 2013.

[34] J. J. F. Hair, W. C. Black, B. J. Babin, and R. E. Anderson, "Multivariate data analysis (7th ed.)". Essex: Pearson Education Limited, 2014.

[35] Y. P. Chua, "Kaedah dan statistik penyelidikan (Buku 2): Asas statistik penyelidikan (2nd ed.)", Kuala Lumpur: McGraw-Hill Education, 2012.

[36] Ministry of Health Malaysia, "Healthy mind module (1st ed.)", Promotion Division of the Ministry of Health Malaysia, 2005.

[37] N. Ahmad, S. Roslan, S. Othman, S. F. A. Shukor, and A. Y. A. Bakar, "The validity and reliability of psychometric profile for depression, anxiety and stress scale (DASS21) instrument among Malaysian undergraduate students", International Journal of Academic Research in Business and Social Sciences, vol. 8(6), pp. 812-827, 2018.

[38] G. B. Çevik, and M. A. Yıldız, "The Role of Perceived Social Support and Coping Styles in Predicting Adolescents' Positivity”, Universal Journal of Educational Research, vol. 5(5), pp. 723-732, 2017.

[39] S. L. Kaplan, M. Nussbaum, P. Skomorowsky, I. R. Shenker, and P. Ramsey, "Health habits and depression in adolescence", Journal of Youth and Adolescence, vol. 9(4), pp. 299-304, 1980.

[40] B. Connelly, and D. Johnston, "The prevalence of depression in a high school population", Adolescence, vol. 28(109), pp. 149-158, 1993.

[41] S. C. Mey, and L. S. Siew, "Kemurungan di kalangan pelajar, Jurnal Pendidikan UTM, vol. 20, pp. 113-129, 2005.

[42] M. N. Omar, and S. N. Ismail, "Mobile technology integration in the 2020s: the impact of technology leadership in the Malaysian context", Universal Journal of Educational Research, vol. 8(5), pp. 1874-1884, 2020.

[43] S. Othman, and A. C. Essau, "Adolescent health risk behaviors and mental health: evidence from the Malaysian National Health and Morbidity Survey 2017. Asia Pacific Journal of Public Health, vol. 31(8), pp. 6S-7S, 2019.

[44] N. Arslan, "Investigating the Relationship between Educational Stress and Emotional Self-Efficacy”, Universal Journal of Educational Research, vol. 5(10), 1736-1740, 2017. 